\title{
Effect of ozone and sulphur dioxide on mycorrhizae of Pinus halepensis Miller
}

\author{
G Díaz¹, O Barrantes², M Honrubia¹, C Gracia² \\ 1 Dept Biología Vegetal, Fac Biología, Univ Murcia, 30100 Murcia; \\ ${ }^{2}$ Creaf, Univ Autónoma de Barcelona, Barcelona, Spain
}

(Received 29 January 1995; accepted 18 September 1995)

\begin{abstract}
Summary - Little information exists on the effect of ozone $\left(\mathrm{O}_{3}\right)$ and sulphur dioxide $\left(\mathrm{SO}_{2}\right)$ on Pinus halepensis Miller. The objective of this work was to determine the effect of these gaseous pollutants alone or in combination on biomass and mycorrhizae of $P$ halepensis. Seedlings were treated for 1 year with filtered air (control), $50 \mathrm{ppb} \mathrm{O}_{3}, 40 \mathrm{ppb} \mathrm{SO}_{2}$ or a mixture of $50 \mathrm{ppb} \mathrm{O}_{3}+40 \mathrm{ppb} \mathrm{SO} \mathrm{O}_{2} \mathrm{O}_{3}$ and $\mathrm{SO}_{2}$ treatments had no significant effect on shoot and root biomass and a slight reduction on percentage of mycorrhizal colonization was noted with $\mathrm{SO}_{2}$. However, these parameters were significantly reduced when the pollutants acted in combination. Morphological alterations of mycorrhizae were also noted, with a reduction in the coralloid structures in favour of simple ones. Moreover, a change in species composition was observed: the ectomycorrhizae probably formed by Suillus species being replaced by ectendomycorrhizae in the $\mathrm{O}_{3}+\mathrm{SO}_{2}$ treatment.
\end{abstract}

\section{biomass / mycorrhizae / Pinus halepensis / ozone / sulphur dioxide}

Résumé - Effet d' $\mathrm{O}_{3}$ et $\mathrm{SO}_{2}$ sur les mycorhizes de Pinus halepensis Miller. Les informations concernant l'effet d'O3 et SO2 sur Pinus halepensis Miller sont rares. L'objectif de ce travail était de déterminer l'effet de ces polluants gazeux, seuls ou en combinaison, sur la croissance et les mycorhizes de $\mathrm{P}$ halepensis. Des semis ont été soumis pendant 1 an à de l'air purifié (témoin), $50 \mathrm{ppb} \mathrm{O}_{3}$,

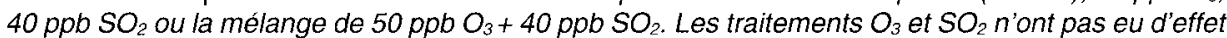
significatif sur la masse des tiges et des racines, ni sur le pourcentage de colonisation mycorhizienne. Cependant, ces paramètres ont été significativement réduits lorsque les deux polluants agisaient en combinaison. Des modifications de la morphologie des mycorhizes ont été notées, avec une réduction des structures coralloïdes en faveur des structures plus simples. De plus, un changement d'espèces fongiques a été observé avec le traitement $\mathrm{O}_{3}+\mathrm{SO}_{2}$ : les ectomycorhizes attribués à Suillus sp ont été remplacés par des ectendomycorhizes.

\section{biomasse / mycorhizes / Pinus halepensis / ozone / sulfure dioxide}

\section{INTRODUCTION}

Atmospheric pollutants may directly or indirectly affect forest productivity. In particular, ozone and sulphur dioxide have been indicated as contributing factors to forest decline in central Europe and North America (McLaughin, 1985). Ozone has been re- 
ported to reduce root growth (Hogsett et al, 1985; Chappelka and Chevone, 1986; Temple, 1988; Schier et al, 1990), and to induce reductions in needle length, seedling height and dry weight (Schier et al, 1990). Reduced photosynthesis (Reich, 1985), changes in allocation patterns (Cooley and Mauning, 1987) and alterations in needles (Ebel et al, 1990; Sutinen et al, 1990; Evans and Leonard, 1991; McQuattie and Schier, 1993) have also been observed in plants exposed to ozone.

Soil microbiological components, such as ectomycorrhizal fungi, could also be affected by atmospheric contaminants. Because of their important role in plant nutrient uptake, tolerance in root diseases, water uptake, etc, effects on mycorrhizal associations could be related to reduced plant growth and damage of coniferous trees.

Nonmycorrhizal seedlings have been generally used to study plant response to ozone or $\mathrm{SO}_{2}$. However, in natural conditions roots are mycorrhized. Therefore, the use of mycorrhizal plants in the experiments is more representative of what occurs in a natural plant-soil system.

Mycorrhizal seedlings exposed to ozone treatments have been reported to be very sensitive and they exhibit reduced percentages of mycorrhizal colonization. Reich et al (1986), McQuattie and Schier (1987, 1992), Stroo et al (1988) and Edwards and Kelly (1992) observed this fact in several Pinus species. In a similar way, mycorrhizal colonization was inhibited in Quercus rubra seedlings by high levels of sulphur dioxide (Reich et al, 1986).

$P$ halepensis Miller (Aleppo pine) is a widely distributed plant species in Mediterranean ecosystems and is well adapted to semiarid conditions. Only few data are available about the effects of gaseous pollutants on $P$ halepensis. Velissariou et al (1992) reported chlorotic mottle in Aleppo pine needles caused by ozone in Attica (Greece) and a possible interaction between ozone and low levels of $\mathrm{SO}_{2}$ near
Athens. Similarly, Sánchez et al (1992) observed the same symptoms on $P$ halepensis needles in specific areas of Spain and Greece, as a consequence of high levels of photochemical oxidant pollution. Ozone might affect the winter recovery of chlorophyll content in needles (Inclán et al, 1993), while Alonso et al (1993) reported an increase in peroxidase activity in ozone fumigated trees, suggesting a possible interaction between high levels of pollutants and Mediterranean climatic stresses. Wellburn and Wellburn (1994) also pointed out the detrimental effect of high levels of $\mathrm{O}_{3}$, which affect the ability of the tree to resist water stress and reported extensive accumulations of starch in needles, particularly in the endodermis. Changes in concentration of fatty acids and chloroplast ultrastructure in response to ozone have also been reported in $P$ halepensis (Anttonen et al, 1995).

Although the effect of ozone and sulphur dioxide on ectomycorrhizae has been studied with several coniferous plant species, to our knowledge, no previous information exists about Aleppo pine.

The objective of this study was to determine the effect of $\mathrm{SO}_{2}$ and $\mathrm{O}_{3}$ alone or in combination on biomass production and mycorrhizal development of $P$ halepensis.

\section{MATERIALS AND METHODS}

Two-year-old $P$ halepensis seedlings of similar height and diameter grown from seed in nursery were transplanted into $35 \times 30 \times 30 \mathrm{~cm}$ plastic pots containing natural soil collected from a previously cultivated, but now abandoned cereal field close to a $P$ halepensis stand in Calanda, Teruel (Spain). Physical and chemical characteristics of the soil are shown in table I.

Plants were placed in chambers equipped for $\mathrm{O}_{3}$ and $\mathrm{SO}_{2}$ fumigation and charcoal filters, in order to avoid the possible entry of pollutants different from those of interest. Four treatments were established: filtered air (FA) without contaminants (control); $\mathrm{FA}+50 \mathrm{ppb}$ of $\mathrm{O}_{3} ; \mathrm{FA}+40$ $\mathrm{ppb}$ of $\mathrm{SO}_{2}$; and $\mathrm{FA}+$ a mixture of $40 \mathrm{ppb}$ of $\mathrm{SO}_{2}$ $+50 \mathrm{ppb}$ of $\mathrm{O}_{3}$. These pollution concentrations, although realistic levels, were above the in- 
mission levels measured in Mediterranean areas (Velissariou et al, 1992). They were chosen in order to accentuate the possible effects in a limited-in-time experiment.

The internal volume of the chambers was $6.9 \mathrm{~m}^{3}$ $\left(\mathrm{O}_{3}\right.$ treatment), $9.5 \mathrm{~m}^{3}$ (control) and $10.2 \mathrm{~m}^{3}\left(\mathrm{SO}_{2}\right.$ and $\mathrm{SO}_{2}+\mathrm{O}_{3}$ treatments). The walls of the chambers were made of glass and covered by a shading film which intercepted about $40 \%$ of incident sunlight. No other sources of light were provided.

The ozone was generated by two dried air feeded Triozon generators. Possible nitrogen oxides were then removed by bubbling the output of the ozonator through a water wash. The ozone and the $1 \%$ in nitrogen $\mathrm{SO}_{2}$ from bottles were conducted to the chambers through stainless steel pipes by means of a pump.

The pollutant concentration was controlled by a system of flowmeters and electrovalves and was continuously measured by three ThermoElectron $43 \mathrm{ASO}_{2}$ analysers and one MonitorLab $\mathrm{O}_{3}$ analyser.

There was a total of 125 seedlings: 32 replicates in control treatment, 35 in $\mathrm{SO}_{2}$ and $\mathrm{SO}_{2}+$ $\mathrm{O}_{3}$ treatments and 25 in $\mathrm{O}_{3}$ treatment.

The temperature (monthly average) oscillated between $10^{\circ} \mathrm{C}$ in January 1993 and $27.5^{\circ} \mathrm{C}$ in July 1992 during the experiment. The relative humidity varied between $46 \%$ in March 1993 and 90\% in January 1993.

Plants were watered when necessary by means of a drip irrigation system.

After 1 year, eight randomly selected seedlings per treatment were harvested, and aerial and root biomass were determined after drying $\left(80^{\circ} \mathrm{C}, 16 \mathrm{~h}\right)$. Nine subsamples from the root system of each selected seedling were taken from the top, middle and bottom root portions and mixed in a bulked sample. Roots were examined for the presence of mycorrhizae under a stereomicroscope, and the mean percentage of mycorrhizal colonization was determined.

Mycorrhizal fungi were isolated from the mycorrhizae in petri dishes with modified-MelinNorkrans medium (MMN) (Marx, 1969). Mycorrhizal tips were washed in a solution of $0.01 \%$ Tween 80 and then in sterile water for $30 \mathrm{~min}$. They were surface sterilized with $30 \% \mathrm{H}_{2} \mathrm{O}_{2}$ for $35 \mathrm{~s}$ and washed again in sterile water before being placed in the medium. Macroscopic and microscopic characteristics of the mycelia were examined.

Light microscopy: Short roots were fixed in formalin acetic alcohol (FAA, 4:1:1), dehydrated in
Table I. Physical and chemical characteristics of the soil used in the experiment.

\begin{tabular}{lr}
\hline $\mathrm{pH}(\mathrm{KCl})$ & 7.58 \\
$\mathrm{CO}_{3}(\%)$ & 23.06 \\
$\mathrm{CaO}$ active $(\%)$ & 8.56 \\
$\mathrm{C}$ org $(\%)$ & 0.30 \\
Organic matter $(\%)$ & 0.52 \\
$\mathrm{~N}(\%)$ & 0.03 \\
$\mathrm{C} / \mathrm{N}$ & 8.82 \\
$\mathrm{P}_{\text {extractable }}(\mathrm{mg} / \mathrm{kg})^{*}$ & 7.03 \\
$\mathrm{~K}$ exchangeable $(\mathrm{meq} / 100 \mathrm{~g})$ & 0.15 \\
$\mathrm{Mg}$ exchangeable $(\mathrm{meq} / 100 \mathrm{~g})$ & 2.80 \\
$\mathrm{Ca}$ exchangeable $(\mathrm{meq} / 100 \mathrm{~g})$ & 12.30 \\
Sand $(\%)$ & 70.90 \\
Silt $(\%)$ & 19.60 \\
Clay $(\%)$ & 10.30 \\
\end{tabular}

* Determined according to the Olsen method (1954).

a graded ethanol series and then infiltrated and embedded in Epon resin. Sections $(0.5-1.0 \mu \mathrm{m})$ were stained with toluidine blue.

Data were subjected to analysis of variance and significant differences between mean values determined by Fischer's least significant difference test (shoot/root biomass) and Duncan's test (percentage of mycorrhizal colonization).

\section{RESULTS}

$\mathrm{O}_{3}$ and $\mathrm{SO}_{2}$ treatments had no significant effect on root biomass. On the other hand, a slight but not significant reduction in shoot and total biomass was observed in plants treated with $\mathrm{O}_{3}$ and $\mathrm{SO}_{2}$ alone. However, plant growth (shoot and root) was significantly affected by these contaminants when they acted in combination. Total biomass was reduced by $25 \%$ compared to controls (table II).

The morphology of pine root systems was also altered. Root elongation and lateral root formation were reduced in the $\mathrm{SO}_{2}+$ $\mathrm{O}_{3}$ treatment.

The percentage of mycorrhizal colonization also decreased significantly with the joint effect of these factors. Neither $\mathrm{SO}_{2}$ nor $\mathrm{O}_{3}$ alone had a strong inhibitory effect on 
Table II. Effect of ozone and sulphur dioxide on shoot and root biomass production in Pinus halepensis seedlings.

\begin{tabular}{lcccc}
\hline Treatment & $\begin{array}{c}\text { Shoot biomass } \\
(g)\end{array}$ & $\begin{array}{c}\text { Root biomass } \\
(g)\end{array}$ & $\begin{array}{c}\text { Total biomass } \\
(g)\end{array}$ & $\begin{array}{c}\text { Root/shoot } \\
(g)\end{array}$ \\
\hline $\mathrm{Control}$ & $47.88^{\mathrm{a}} \pm 6.51$ & $24.13^{\mathrm{a}} \pm 3.57$ & $72.01^{\mathrm{a}} \pm 9.94$ & $0.50^{\mathrm{b}} \pm 0.03$ \\
$\mathrm{SO}_{2}$ & $43.36^{\mathrm{ab}} \pm 6.89$ & $23.11^{\mathrm{a}} \pm 3.77$ & $66.47^{\mathrm{ab}} \pm 10.39$ & $0.53^{\mathrm{ab}} \pm 0.04$ \\
$\mathrm{O}_{3}$ & $40.87^{\mathrm{ab}} \pm 8.63$ & $23.21^{\mathrm{a}} \pm 3.37$ & $64.08^{\mathrm{ab}} \pm 11.53$ & $0.58^{\mathrm{a}} \pm 0.07$ \\
$\mathrm{SO}_{2}+\mathrm{O}_{3}$ & $38.36^{\mathrm{b}} \pm 13.43$ & $15.41^{\mathrm{b}} \pm 5.85$ & $53.78^{\mathrm{b}} \pm 18.86$ & $0.40^{\mathrm{c}} \pm 0.08$
\end{tabular}

Data expressed as mean and standard error of eight replicates. Values followed by the same letter in a treatment are not significantly different $(P<0.05)$.

the formation and development of ectomycorrhizae (fig 1).

Two morphological types of mycorrhizae were observed. One of them occurred in the four treatments. Ectomycorrhizae were simple, dichotomous and mainly coralloid, $1.5-4 \mathrm{~mm}$ in length, normally stipped with a base up to $5 \mathrm{~mm}$ long. The surface was white to pink, with a silvery appearance due to air enclosed between the mantle hyphae (densely cottony mantle with extramatrical hyphae between dichotomies). Rhizomorphs were white to pinkish brown.

The combination of $\mathrm{O}_{3}$ and $\mathrm{SO}_{2}$ also affected the morphology and development of mycorrhizae. Control, $\mathrm{O}_{3}$ and $\mathrm{SO}_{2}$ usually exhibited dichotomous and coralloid structures, with a well-developed mantle. In contrast, roots treated with $\mathrm{SO}_{2}+\mathrm{O}_{3}$ showed a reduction of coralloid structures with a predominance of simple, unramified ectomycorrhizal tips. The percentage of coralloid structures decreased significantly in this treatment (fig 1).

Several isolates were obtained after the culture of this morphotype. Their comparison with a fungal isolate collection made their identification possible in some cases. The morphological features were as follows:

i) Mycelium pink brown, superficial, regular margin, brown reverse. Hyaline hyphae, simple ramification, $3-5 \mu \mathrm{m}$ wide, thin walls. Similar to Suillus sp. ii) Mycelium pinkish-brown. Aerial mycelium white, cottony, densely distributed on the colony. Regular margin, sometimes dark brown. Brown-yellowish reverse. With exudates of yellow pigments. Hyaline hyphae, simple ramification, 3-5 $\mu \mathrm{m}$ wide, thin walls. Similar to Suillus sp.

iii) Mycelium initially white, then cream. Aerial mycelium white, cottony, densely dis-

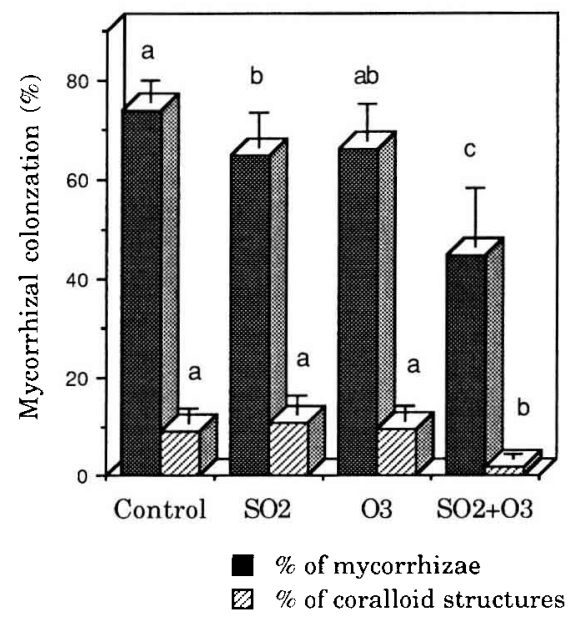

Fig 1. Effect of ozone $\left(\mathrm{O}_{3}\right)$ and sulphur dioxide $\left(\mathrm{SO}_{2}\right)$ on total percentage of mycorrhizal colonization and percentage of coralloid structures on Pinus halepensis seedlings. Data expressed as mean and standard error of eight replicates. Values with the same letter in a parameter are not significantly different $(P<0.05)$ 

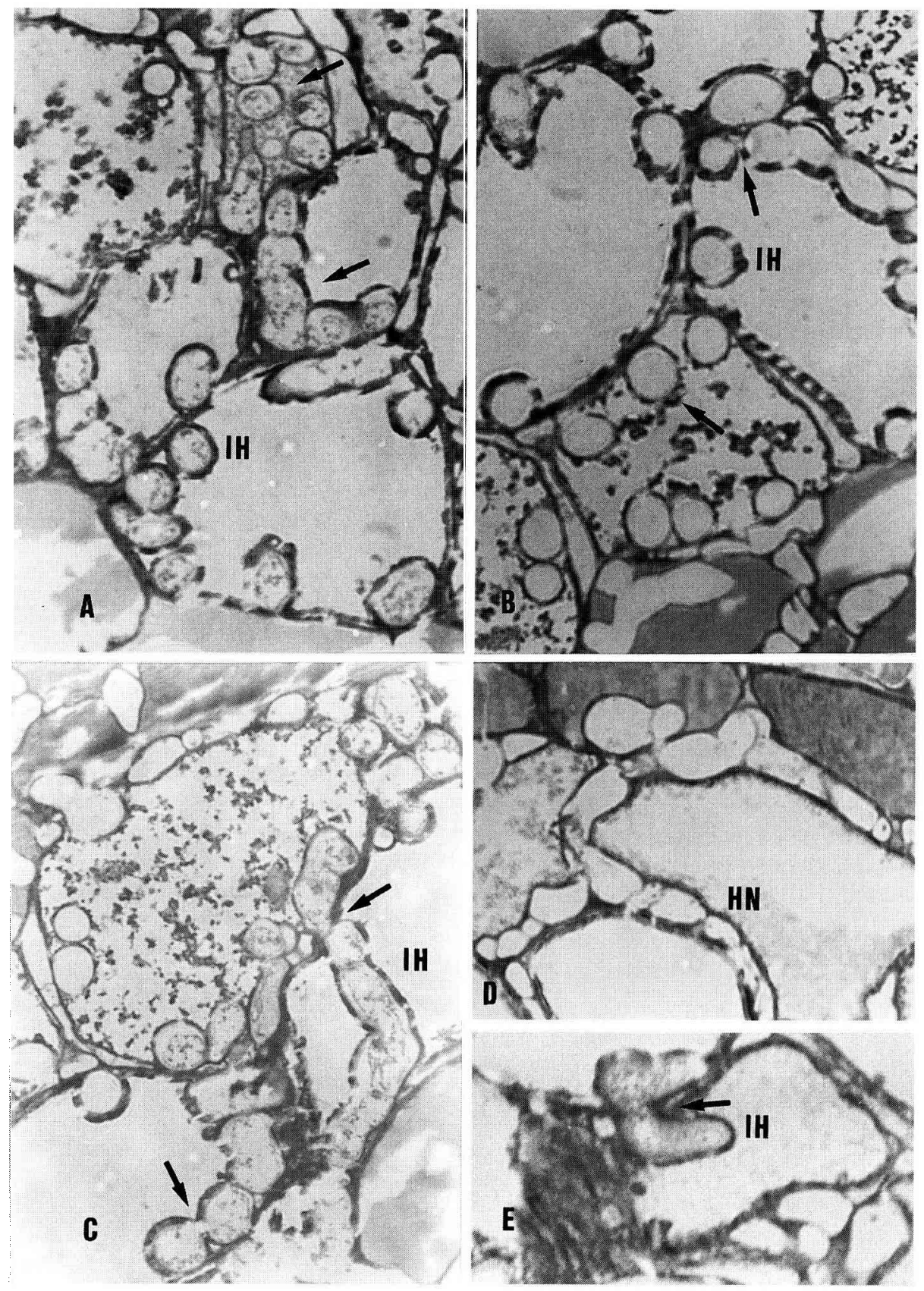

Fig 2. Semi-thin sections of ectendomycorrhizae in the $\mathrm{SO}_{2}+\mathrm{O}_{3}$ treatment showing intracellular hyphae $(\mathrm{IH})$ and the Hartig net (HN). A-D: x 1 000; E: x 1500. 
tributed on the colony. Regular margin. Reverse brown in the middle, yellowishwhite in the margin. With exudates of light yellow pigments. Hyaline hyphae, simple ramification, $2.5-4.5 \mu \mathrm{m}$ wide, thin walls.

iv) Mycelium initially white, then brown. Aerial myceliym white, cottony, irregularly distributed on the colony, with radial folds. Dark brown reverse. Hyaline hyphae, simple ramification, 3-5 $\mu \mathrm{m}$ wide, thin walls. Similar to Suillus collinitus.

The other morphotype was of the ectendomycorrhizal type. It appeared only in the $\mathrm{SO}_{2}+\mathrm{O}_{3}$ treatment $(50 \%$ of the studied seedlings) and some seedlings of the $\mathrm{O}_{3}$ treatment ( $28 \%$ of seedlings). Ectendomycorrhizae were simple, $1-2.5 \mathrm{~mm}$ in length and $0.5-1.5 \mathrm{~mm}$ in width and brown to dark brown in older roots, except at the apices which were lighter. The mantle was poorly developed to lacking, with a smooth surface and sometimes emanating hyphae. They were differentiated from nonmycorrhizal root tips by the absence of root hairs, a swollen appearance and the examination of hand-cross sections for the presence of Hartig net. The presence of intracellular hyphae in stained sections, as well as a thin mantle and a well-developed Hartig net, proved that they were ectendomycorrhizae (fig 2). Attemps to isolate the mycosymbiont in MMN medium failed.

\section{DISCUSSION}

The main conclusion that can be drawn under the experimental conditions is that the combination of $\mathrm{SO}_{2}$ and $\mathrm{O}_{3}$ had a greater negative effect on biomass and mycorrhizal colonization of $P$ halepensis than either substance alone, suggesting a synergic interaction of these gaseous pollutants. The effects of $\mathrm{SO}_{2}$ or $\mathrm{O}_{3}$ on biomass production and mycorrhizal associations are related to alterations of photosynthesis and metabolism of plants, mediated by changes in stomatal aperture, carbon-fixing enzymes, $\mathrm{pH}$ buffering ca- pacity and disruption of the integrity of membranes (Guderian, 1985; Kozlowsky et al, 1991). Whilst the mechanisms of action of $\mathrm{SO}_{2}$ and $\mathrm{O}_{3}$ separately are quite well known, those of the mixture remain unclear. It is generally accepted that the mixture of both $\mathrm{SO}_{2}$ and $\mathrm{O}_{3}$ seems to lower the threshold doses of damage for the single components (Darrall, 1989). The formation of free radicals, ie, molecules with unpaired electrons, and radical-chain mechanisms seem to be involved in this process (Weigel et al, 1989; Elstner and Osswald, 1991).

$\mathrm{O}_{3}$ and $\mathrm{SO}_{2}$ do not penetrate the soil surface, so direct effects of these pollutants on mycorrhizae are not likely. Indirect effects are mediated by the plant, due to the reduced photosynthesis and therefore the decreased allocation of carbohydrates to the root (Reich et al, 1985; Dighton, 1988; Dighton and Jansen, 1991). It is widely accepted that the availability of carbohydrates is a limiting factor for the development of mycorrhizal infection. On the other hand, proton excretion by the roots and sulphate translocation from leaves to roots have been reported in $\mathrm{SO}_{2}$ fumigated plants (Kaiser et al, 1993). This fact could also explain the detrimental effect of $\mathrm{SO}_{2}$ in mycorrhizal colonization.

Reductions in plant biomass and percentage of colonization seem to be a general fact. However, it is also remarkable that $\mathrm{O}_{3}$ and $\mathrm{SO}_{2}$ not only affected mycorrhizal infection but produced qualitative changes in the mycorrhizae.

Firstly, morphological alterations were noted, with a significant reduction in the coralloid structures in favour of simple or dichotomous ones. McQuattie and Schier (1987, 1992) also observed reduction of the coralloid form of a Pisolithus tinctorius ectomycorrhiza on Pinus rigida due to fumigation with $\mathrm{O}_{3}$ and the presence of $\mathrm{Al}$ in the nutrient solution, as well as other anatomical alterations such as deterioration of fungal mantle and reduction of Hartig net. 
Dighton and Skeffington (1987) reported the suppression of a coralloid ectomycorrhiza of $P$ sylvestris due to acid rain.

On the other hand, mycorrhizal symbiosis did not disappear completely, but a change in species composition occurred. The presence of ectendomycorrhizae in the $\mathrm{SO}_{2}+\mathrm{O}_{3}$ and $\mathrm{O}_{3}$ treatments revealed that the pollutants may selectively inhibit certain species and favour other more resistant ones. It is generally accepted that diversity stabilizes the plant-soil system during stress. Different species differ in their tolerances, physiological requirements, etc. The altered environment results in a replacement of one mycorrhizal fungal species by another, but the plant retains the mycorrhizal component (Perry et al, 1989). These changes in species composition under stress caused by acidification or $\mathrm{SO}_{2}$ and $\mathrm{O}_{3}$ deposition have been reported under natural and experimental conditions (Dighton and Skeffington, 1987; Markkola and Ohtonen, 1988; Meier et al, 1989; Dighton and Jansen, 1991).

In our case, ectomycorrhizae were formed by several Suillus species or strains. The soil used for the experiment probably contained the mycorrhizal propagules from the surrounding pine stand. This genus is very common in $P$ halepensis forests and it has been found to form ectomycorrhizae with this pine (Torres et al, 1991; Torres and Honrubia, 1994). These Suilus fungal species were replaced by ectendomycorrhizal associations formed by E-strain complex fungi in $\mathrm{SO}_{2}+\mathrm{O}_{3}$ treatment, suggesting their tolerance to stress conditions. E-strain fungi are often mycorrhizal symbionts of $P$ halepensis in nurseries (unpublished data) and they have recently been found to form ectendomycorrhiza with $P$ halepensis in burned forests (Torres, personal communication). These observations may lead to the conclusion that they are pioneer species, resistant to stress conditions and able to form mycorrhizal associations when other fungi cannot.
Further research on the differences in susceptibility to atmospheric pollutants among fungal species and their implications in plant nutrition must be undertaken.

\section{ACKNOWLEDGMENTS}

This study was conducted at the Electric Power Plant of Andorra (Teruel, Spain) and supported by the National Electric Company ENDESA.

\section{REFERENCES}

Adams MB, O Neill EG (1991) Effects of ozone and acidic deposition on carbon allocation and mycorrhizal colonization of Pinus taeda $L$ seedlings. For Sci 37, 5-16

Alonso R, Bermejo V, Elvira S, Castillo HJ (1993) Changes of extracellular peroxidase activity induced by natural levels of ozone in Eastern Spain. In: Plant Peroxidases: Biochemistry and Physiology (KG Wellinder et al, eds), Univ Geneva, Switzerland

Anttonen S, Herranen J, Peura P, Kärenlampi L (1995) Fatty acids and ultrastructure of ozone-exposed Aleppo pine (Pinus halepensis Mill) needles. Environ Pollut 87, 235-242

Chappelka AH, Chevone $\mathrm{BI}$ (1986) White ash seedling growth response to ozone and simulated acid rain. Can J For Res 16, 786-790

Cooley DR, Mauning WJ (1987) The impact of ozone on assimilate partitioning in plants: a review. Environ Pollut 47, 95-113

Darrall NM (1989) The effect of air pollutants on physiological processes in plants. Plant Cell Environ 12, 1-30

Dighton J (1988) Some effects of acid rain on mycorrhizas of Scots Pine and potential consequences for forest nutrition. In: Ectomycorrhiza and Acid Rain. Proceedings of the Workshop on Ectomycorrhiza/Expert Meeting (AE Jansen, J Dighton, AH Bresser, eds), Bilthoven, the Netherlands, 104-111

Dighton J, Jansen AE (1991) Atmospheric pollutants and ectomycorrhizae: more questions than answers? Environ Pollut 73,179-204

Dighton J, Skeffington RA (1987) Effects of artificial acid precipitation on the mycorrhizae of Scots pine seedlings. New Phytol 107, 191-202

Ebel B, Rosenkranz J, Schiffgens A, Lutz C (1990) Cytological observations on spruce needles after prolonged treatment with ozone and acid mist. Environ Pollut 64, 323-335

Edwards GS, Kelly JM (1992) Ectomycorrhizal colonization of loblolly pine seedlings during three growing seasons in response to ozone, acidic precipitation, and soil Mg status. Environ Pollut 76, 71-77

Elstner EF, Osswald W (1991) Air pollution: involvement of oxygen radicals (a mini review). Free Rad Res Comms 12-13, 795-807

Evans LS, Leonard MR (1991) Histological determination of ozone injury symptoms of primary needles of 
giant sequoia (Sequoiadendron giganteum Bucch) New Phytol 117, 557-564

Guderian R (1985) Air pollution by phytochemical oxidants: formation, transport, control and effects on plants. Springer-Verlag, Heidelberg

Hogsett WE, Plocher M, Wildman V, Tingey DT, Bennet JP (1985) Growth response of two varieties of slash pine seedlings to chronic ozone exposures. Can J Bot 63, 2369-2376

Inclán R, Elvira S, Gil JM, Velissariou D, Gimeno B, Davison $A(1993)$ Interacción entre la contaminación atmosférica y los factores ambientales en la fisiología del pino carrasco. Resultados preliminares. Congreso forestal español, Lourizán 1993. Ponencias y comunicaciones $3,435-440$

Kaiser WM, Höfler M, Heber U (1993) Can plants exposed to $\mathrm{SO}_{2}$ excrete sulfuric acid through the roots? Plant Physiol 87, 61-67

Kozlowsky TT, Kramer PJ, Pallardy SG (1991) The Physiological Ecology of Woody Plants. Academic Press, New York, USA

Markkola AM, Ohtonen R (1988) The effect of acid deposition on fungi in forest humus. In: Ectomycorrhiza and Acid Rain. Proceedings of the Workshop on Ectomycorrhiza/Expert Meeting (AE Jansen, J Dighton, AH Bresser, eds), Bilthoven, the Netherlands

Marx DH (1969) The influence of ectotrophic mycorrhizal fungi on the resistance of pine roots to pathogenic infections. I. Antagonism of ectomycorrhizal fungi to root pathogenic fungi and soil bacteria. Phytopathology 59, 153-163

McLaughin SB (1985) Effects of air pollution on forests. A review. J Air Pollut Control Ass 35, 312-314

McQuattie CJ, Schier GA (1987) Effects of ozone and aluminium on pitch pine ectomycorrhizae. In: Mycorrhize in the Next Decade. Practical Applications and Research Priorities. Proc of the 7th NACOM (DM Sylvia, LL Hung, JH Graham, eds), Gainesville, FL, USA

McQuattie CJ, Schier GA (1992) Effect of ozone and aluminium on pitch pine (Pinus rigida) seedlings: anatomy of mycorrhizae. Can J For Res 22, 1901-1916

McQuattie CJ, Schier GA (1993) Effect of ozone and aluminium on pitch pine (Pinus rigida) seedlings: needle ultrastructure. Can J For Res 23, 1375-1387

Meier S, Robarge WP, Bruck RI, Grand LF (1989) Effects of simulated rain acidity on ectomycorrhizae of red spruce seedlings potted in natural soil. Environ Pollut 59, 315-324

Olsen SR, Cole CV, Watanabe FS, Dean LA (1954) Stimation of available phosphorus in soil by extraction with sodium bicarbonate. Cir US Dep Agric 939

Perry DA, Amaranthus MP, Borchers JG, Borchers SI, Brainerd RE (1989) Bootstrapping in ecosystems. Internal interactions largely determine productivity and stability in biological systems with strong positive feedback. BioScience 39, 230-237

Reddy GB, Reinert RA, Eason G (1991) Enzymatic changes in the rhizosphere of loblolly pine exposed to ozone and acid rain. Soil Biol Biochem 23, 1115-1119
Reich PB (1985) Effects of low concentrations of $\mathrm{O}_{3}$ on net photosynthesis, dark respiration and chlorophyll contents in aging hybrid poplar leaves. Plant Physiol 73, 291-296

Reich PB, Schoettle AW, Stroo HF, Trojano J, Amundson $R G$ (1985) Effects of $\mathrm{O}_{3}, \mathrm{SO}_{2}$, and acidic rain on mycorrhizal infection in northern red oak seedlings. Can J Bot 63, 2049-2055

Reich PB, Schoettle AW, Stroo HF, Amundson RG (1986) Acid rain and ozone influence mycorrhizal infection in tree seedlings. $J$ Air Pollut Control Ass 36, 724-726

Ruark GA, Thornton PC, Marks AE, Lockaby BG, Chapelka AH, MeldahI RS (1991) Exposing loblolly pine seedlings to acid precipitation and ozone: effects on soil rhizosphere chemistry. Journ Env Qual 20, 828-832

Sánchez GB, Velissariou D, Barnes JD, Inclán R, Peña JM, Davison A (1992) Daños visibles por ozono en acículas de Pinus halepensis Mill en Grecia y en España. Ecologia 6, 131-134

Schier GA, McQuattie CJ, Jensen KF (1990) Effect of ozone and aluminium on pitch pine (Pinus rigida) seedlings: growth and nutrient relations. Can J For Res 20, 1714-1719

Stroo HF, Reich PB, Schoettle AW, Amundson RG (1988) Effects of ozone and acid rain on white pine (Pinus strobus) seedlings grown in five soils. II. Mycorrhizal infection. Can J Bot 66, 1510-1516

Sutinen S, Skarby L, Wallin G, Sellden G (1990) Longterm exposure of Norway spruce, Picea abies (L) Karst, to ozone in open-top chambers. II. Effects on the ultrastructure of needles. New Phytol 115, 345-355

Temple PJ (1988) Injury and growth of Jeffrey pine and giant sequoia in response to ozone and acid mist. Environ Exp Bot 28, 323-333

Torres P, Honrubia M (1994) Inoculation of containerized Pinus halepensis (Miller) seedlings with basidiospores of Pisolithus arhizus (Pers), Rhizopogon roseolus (Corda) Th M Fr and Suillus collinitus ( $\mathrm{Fr}$ ) $\mathrm{O}$ Kuntze. Ann Sci For 51, 521-528

Torres $\mathrm{P}$, Honrubia M, Morte MA (1991) In vitro synthesis of ectomicorrhizae between Suillus collinitus $(\mathrm{Fr}) \mathrm{O}$ Kuntze and Rhizopogon roseolus (Corda) Th M Frwith Pinus halepensis Miller. Mycotaxon 41, 437-443

Velissariou D, Davison AW, Barnes JD, Pfirmann T, Mac Lean DC, Holevas CD (1992) Effects of air pollution on Pinus halepensis (Mill): pollution levels in Attica, Greece. Atmospheric Environ 26A, 373-380

Walker RF, McLaughing SB (1991) Growth and root system development of white oak and loblolly pine affected by simulated acidic precipitation and ectomycorrhizal inoculation. For Ecol Manage 46, 123-133

Weigel HJ, Halbwachs G, Jager HJ (1989) The effects of air pollutants of forest trees from a plant physiological view. J Plant Dis Prot 96, 203-217

Wellburn FAM, Wellburn AR (1994) Atmospheric ozone affects carbohydrate allocation and winter hardiness of Pinus halepensis (Mill). J Exp Bot 45, 607-614 